\title{
Comparative analysis of microbial reduction using photodynamic therapy in bovine teeth infected with Enterococcus faecalis - an in vitro study
}

Janaina Guzzo Zechin ${ }^{\mathrm{a}}$, Liviu Steier ${ }^{\mathrm{b}}$, Giampiero Rossi-Fedele ${ }^{\mathrm{a}, \mathrm{b}}$, Grasiela Longhi Gründling ${ }^{\mathrm{a}}$, Daniela Sác, Amanda Guwzinskic ${ }^{c}$ Alessandra Cesar Trindade ${ }^{a}$, Matheus Albino Souza ${ }^{a, d}$, Silvia Dias de Oliveira ${ }^{c}$, José Antônio Poli de Figueiredo ${ }^{a}$

\begin{abstract}
Objective: To evaluate the use of optic fiber and different pre-irradiation times (PIT) in phototherapy with LED for the root canal disinfection of bovine teeth infected in vitro with Enterococcus faecalis. Methodology: The teeth were incubated for 60 days and divided into six groups according to disinfection protocol: Group 1 - distilled water; Group 2 - 1 minute PIT and no optic fiber; Group 3 1 minute PIT and optic fiber; Group $4-5$ minute PIT and no optic fiber; Group $5-5$ minute PIT and optic fiber; Group 6 - 2\% sodium hypochlorite. Microbiological test (CFUs counting) and scanning electron microscopy (SEM) were performed to evaluate the effectiveness of proposed treatments. Results: SEM analysis of canal wall, in the three thirds, revealed group 6 had the best results, whereas microbiological results revealed that group 6 had the best results. No differences in disinfection of root canals were found when optic fiber was used for photodynamic therapy.

Conclusion: Photodynamic therapy should not be used alone in the disinfection of root canals, but it may be valuable as a complement for disinfection performed using different cleaning methods.
\end{abstract}

Key words: Biofilm; Bovine teeth; Enterococcus faecalis; Photodynamic therapy

Análise comparativa de redução microbial usando terapia fotodinâmica em dentes bovinos infectados com Enterococcus faecalis - um estudo in vitro RESUMO

Objetivo: Avaliar, in vitro, o uso da fibra óptica e diferentes tempos de pré-irradiação (PIT) na terapia fotodinâmica para a descontaminação do canal radicular de dentes bovinos infectados com Enterococcus faecalis.

Metodologia: Os dentes foram incubados por 60 dias e divididos em 6 grupos de acordo com o protocolo de descontaminação: Grupo 1 - água destilada; Grupo 2 - 1 minuto de pré-irradiação sem fibra óptica; Grupo 3 - 1 minuto de pré irradiação com fibra óptica; Grupo 4 - 5 minutos de pré-irradiação sem fibra óptica; Grupo 5 - 5 minutos de pré-irradiação com fibra óptica; Grupo 6 - hipoclorito de sódio 2\%. Teste microbiológico (contagem de UFCs) e microscopia eletrônica de varredura (MEV) foram realizados para avaliar a eficácia dos tratamentos propostos.

Resultados: A análise em microscopia electronica de varredura das paredes do canal radicular, nos três terçoes, bem como a análise microbiológica, revelou que o grupo 6 obteve o melhor resultado no processo de descontaminação. Não foram encontradas diferenças estatisticamente significantes na desinfecção do canal radicular comparando o uso ou não da fibra óptica.

Conclusão: Terapia fotodinâmica isoladamente não deveria ser utilizada na desinfecção do canal radicular, mas pode ser uma alternative viável como complemento a partir da utilização de diferentes métodos de limpeza.

Palavras-chave: Biofilme; Dentes bovinos; Enterococcus faecalis; Terapia fotodinâmica a School of Dentistry, Pontifical Catholic University of Rio Grande do Sul, Porto Alegre, RS, Brazil.

${ }^{\mathrm{b}}$ Warwick Dentistry, Warwick Medical School, Warwick, United Kingdom.

${ }^{c}$ School of Biosciences, Pontifical Catholic University of Rio Grande do Sul, Porto Alegre, RS, Brazil.

${ }^{d}$ School of Dentistry, University of Passo Fundo, Passo Fundo, RS, Brazil 


\section{INTRODUCTION}

Enterococcus faecalis, a Gram-positive anaerobic facultative coccus, plays an important role in the failure of endodontic therapy; it is often found in chronic periapical lesions in cases of endodontic retreatment [1-3]. Its virulence is associated with its resistance to most frequently used intracanal medications and its capacity to survive in root canals without the support of other bacteria [4-6].

Photodynamic therapy (PDT) has been described as an alternative for the disinfection of root canals, and results have been positive, particularly when used against E. faecalis [7-10]. It uses low density light (laser or LED) associated with exogenous photosensitizers that absorb light and trigger chemical events that result in the production of oxygen reactive species, which are toxic to tumor cells, bacteria and fungi $[7,8,11]$. Ortho-toluidine blue (tolonium chloride), when used as photosensitizer, has been proven to have a bactericide effect [12].

Several LED or laser units do not have an optic fiber delivery mode. In these cases, and if an optic fiber is proven to affect the results, these units would not have any use in endodontic treatments. However, if the laser beam or LED has enough penetration to reach the photosensitizer even from a distance, the use of optic fibers would be unnecessary, the chances of using PDT would increase, and costs would be reduced. Therefore, it is necessary to know how this treatment would act on consolidated biofilm with microorganisms that are resistant to traditional therapies.

Moreover, there is no consensus in the literature about which protocol to use in adjuvant photodynamic therapy during conventional endodontic treatment. This study compared the effect of the use of an optic fiber and different pre-irradiation times (PIT) using red light LED to clean root canals infected with $E$. faecalis.

\section{MATERIALS AND METHODS}

This study was approved by the Ethics Committee for the Use of Animals (CEUA) of Pontifical Catholic University of Rio Grande do Sul (PUCRS) under number 10/00163.

\section{Sample obtaining and preparation}

One hundred and twenty six bovine incisors were obtained from animals slaughtered for commercial purposes. Teeth were removed from the mandibles immediately after slaughtering and were stored in 1\% sodium hypochlorite (ASPER, Indústria Química Ltda, São Caetano do Sul, Brazil) for no longer than $48 \mathrm{~h}$. Dental crowns and $1 \mathrm{~mm}$ of the apical region were sectioned so that all roots measured $15 \mathrm{~mm}$ long. To remove the pulp and have a uniform canal diameter, each root was prepared up to the instrument \#60 (Dentsply-Maillefer, Ballaigues, Switzerland) using irrigation with $2 \%$ sodium hypochlorite ( $2 \%$ Virex Plus, Johnson Diversey Brasil Ltda, São Paulo, Brazil). After that, the roots were kept immersed in 17\% EDTA (Farmashop,
Porto Alegre, Brazil) for 5 minutes under agitation to remove the smear layer.

\section{Culture and inoculum preparation}

The 126 teeth were fixed in a polypropylene microtube (Genuine Axygen Quality, CA) with cyanoacrylate (Super Bonder, São Paulo, Brazil) to keep it vertical with the coronal side up. The teeth were randomly divided into six groups and placed in 6 polypropylene boxes (Heathrow, Vernon Hills, IL). After that, the canal to each root was sealed with autoclave tape (3M do Brasil, Sumaré, Brazil), and a hole was made in the microtube cap to make it possible to change BHI (Brain Heart Infusion - Difco Laboratories, Detroit, USA) during incubation. After mounting, the set formed by the box and tubes with specimens were autoclaved (Kavo, Joinville, Brazil) at $121^{\circ} \mathrm{C}$ for 15 minutes.

Specimen sterilization was evaluated using one tooth from each group. After sterilization of each propylene box with teeth, a sterile paper cone was put inside the root canal to collect possible contaminant material. This cone was immediately inoculated in a tube with sterile saline solution at $0,85 \%$, homogenized and, after 5 minutes, an aliquot of $100 \mu \mathrm{L}$ of the saline solution containing the cone was cultivated in duplicate on blood agar and incubated for 18 to 24 hours at $37^{\circ} \mathrm{C}$. After that procedure, examination showed that there was no contamination originating from the sampled tooth, which confirmed the sterilization of the material. The specimen used for sterilization control was removed from the box and discarded, remaining 20 teeth per box.

The E. faecalis (ATCC 29212) was obtained and cultivated in BHI broth for 18 to 24 hours at $37^{\circ} \mathrm{C}$ in a bacteriological incubator, in the Immunology and Microbiology Laboratory of the School of Biosciences, PUCRS.

The number of colony forming units $(\mathrm{CFU} / \mathrm{mL})$ of the inoculum was determined by counting the colonies on blood agar. For that, the culture of E. faecalis was diluted serially up to $10^{-8}$ in $0.85 \%$ saline solution, and $100 \mu \mathrm{L}$ of the dilutions $10^{-6}, 10^{-7}$ and $10^{-8}$ were cultivated in duplicate on blood agar using a sterilized Drigalsky handle. The plates were incubated at $37^{\circ} \mathrm{C}$ for 24 hours, after which $\mathrm{CFU} / \mathrm{mL}$ were counted in the plates that had 15 to 150 colonies. Bacterial density ranged from $4.0 \times 10^{8}$ to $7.2 \times 10^{8}$.

The 120 samples were inoculated with $100 \mu \mathrm{L}$ of the culture of E. faecalis into the root canal. Sterile BHI was then added to the plastic tube so that was completely filled with culture medium. The culture of E. faecalis was maintained for 60 days for the formation of biofilm, and one third of the BHI was replaced every 48 hours. All teeth were handled under aseptic conditions in a laminar flow hood. Once a week, an aliquot of BHI of the teeth was Gram stained, cultured in blood agar, and submitted to catalase and esculin tests to confirm the exclusive presence of $E$. faecalis.

\section{Classification of the groups}

Teeth were loosened from the tubes and mounted in a utility wax base (Wilson, Polidental, Cotia, Brazil) to avoid 
overflowing of the irrigating solution and photosensitizers through the apical foramen.

Working length was established at $14 \mathrm{~mm}$, and the groups were divided as described below:

- Group 1 (control, $\mathrm{n}=20$ ): irrigation with distilled water that filled up the root canals and was kept inside the canal for one minute; aspiration of the irrigating solution with a $5 \mathrm{~mL}$ disposable plastic syringe (BD, Curitiba, Brazil). Each sample received four irrigations at 30 second intervals. Results of this group served as the basis for comparison with other groups; this was considered the pretreatment counting.

- Group $2(\mathrm{n}=20)$ : canals were irrigated using a $5 \mathrm{~mL}$ disposable plastic syringe with $2 \mathrm{~mL}$ of distilled water that was later aspirated also using a $5 \mathrm{~mL}$ disposable syringe. The canals were then filled up with $0.001 \%$ ortho-toluidine blue (tolonium chloride) viscous photosensitizer using a $5 \mathrm{~mL}$ disposable syringe. After 1 minute, tolonium chloride was stirred with a 21-mm-long \#50 file at $14 \mathrm{~mm}$ without touching the walls of the root canal. The LED beam was activated for 120 seconds using a PAD Plus unit (Denfotex Light Systems Ltd, Inverkeithing, United Kingdom) and 630-nm red light; the optic fiber was not coupled to the LED tip, and the pointer was placed at the canal entrance.

- Group $3(n=20)$ : the procedure was the same as for group 2, but an optic fiber was coupled to the LED tip. The stationary technique was used: the irradiation is distributed along the three thirds of the root canals using preprogrammed pullbacks at three time points, also at a total of 120 seconds.

- Group $4(n=20)$ : the procedure was similar to that followed in group 2, but PIT was 5 minutes and the ortho-toluidine blue photosensitizer was not stirred.

- Group $5(\mathrm{n}=20)$ : the procedure was again the same as in group 2, but PIT time was 5 minutes, the photosensitizer was not stirred and the optic fiber was coupled to the LED tip; the stationary technique was the same as in group 3 .

After irradiation, the canals in each group were irrigated again with $2 \mathrm{~mL}$ distilled water using a $5 \mathrm{~mL}$ disposable plastic syringe and aspirated also with a $5 \mathrm{~mL}$ disposable plastic syringe.

- Group $6 \quad(\mathrm{n}=20)$ : irrigation with $2 \%$ sodium hypochlorite that filled up the root canals and was kept inside the canal for one minute; all the solution was then aspirated using a $5 \mathrm{~mL}$ disposable plastic syringe. Each sample received four irrigations at 30 second intervals.

\section{SEM analysis}

Immediately after treatment, 10 teeth from each group were immersed in a fixing solution (2.5\% glutaraldehyde) for 7 days for later analysis under scanning electron microscopy (SEM) in the Electronic Microscopy and Microanalysis Center of PUCRS.
Roots were rinsed three times for 30 minutes each time in a $0.2 \mathrm{~mol} / \mathrm{L}$ phosphate buffer and distilled water at a 1:1 ratio. After that, they were dehydrated by immersion in $30,50,70,90$ and $100 \%$ acetone. Longitudinal buccolingual grooves were produced on the free surfaces of the roots using a diamond bur (Dhpro, Rhadartrade, Paranaguá, Brazil); care was taken not to penetrate the interior of the root canal. Root fracture was completed using a \#50 spatula (SS White, Rio de Janeiro, Brazil) to obtain two halves that were mounted in stubs with the root canal end up. After that, the samples were spurted-coated with gold for electron conduction.

A scanning electron microscope (Phillips XL-30, Eidhoven, Holland) was used for evaluations of roots according to thirds (coronal, middle and apical) at 500X to 20000X magnification. First, areas of greater concentration of biofilm were selected at a lower magnification; recordings were then made at 5000X magnification. Backscattering (BSE) was used for image capture.

One single observer blinded to the experimental groups classified images according to the presence of bacteria and using the criteria of position ranks.

Adopting the PowerPoint program (Microsoft Corp, Redmond, WA), each image occupied a slide, which was transferred to the computer screen in the form of presentation. The images were modified in position according to the level of contamination found, so that number 1 was the least contaminated and number 60 the most contaminated. This classification by rank was performed on each third (coronal, middle, and apical) by the location of the image (canal wall and exposed tubule area). Then, for each third and for each image location, the average position of the group was calculated.

For a difference of at least 1.5 standard deviation between mean counts in the groups, reaching a $90 \%$ statistical power with a significance level of $5 \%$, a number of 10 specimens was calculated for each group.

\section{Microbiological analysis}

After treatment, 10 teeth from each group were used for microbiological analysis. Their canals were immediately filled with sterile saline solution, stirred with a \#50 file at 14 $\mathrm{mm}$ for 15 seconds, touching the canal walls. An aliquot of $50 \mu \mathrm{L}$ of the solution was removed from the canal and placed into a tube with $450 \mu \mathrm{L}$ of sterile saline solution at $0.85 \%$. The material was homogenized and diluted to $10^{-3}$. Aliquots of $100 \mu \mathrm{L}$ of the solution and the dilutions were cultivated in duplicate on blood agar using a Drigalsky handle and incubated for 18 to 24 hours at $37^{\circ} \mathrm{C}$. After incubation, the number of CFU's was counted in the plates that had 15 to 150 colonies.

Data on levels of contamination measured with electronic microscopy were ranked within thirds. One-way ANOVA was applied to ranks with a robust significance, followed by the Tukey post hoc test to detect differences.

In the microbiology evaluation, all data were log transformed. One-way ANOVA was followed by the Tukey post hoc test. 
The level of significance was set to $\alpha=0.05$. Data were analyzed using the SPSS 17.0 (SPSS, Chicago, IL).

\section{RESULTS}

SEM analysis

The effectiveness of proposed treatments is shown in Figure 1 and Table 1, which summarizes findings of SEM analysis.
In the canal wall, in the three thirds, group 6 (Figure 2) had the best results, there were statistically significant differences between this group and the groups 1, 3, 4 and 5 $(\mathrm{p}<0,001)$. Group 2 (Figure 3 ) had the best results between groups of photodynamic therapy, in the three thirds. There were statistically significant differences between group 2 and groups 4 and 5 in apical and middle thirds, and between group 2 and groups 1 (Figure 4$), 4$ and $5(p<0,001)$ in coronal third.

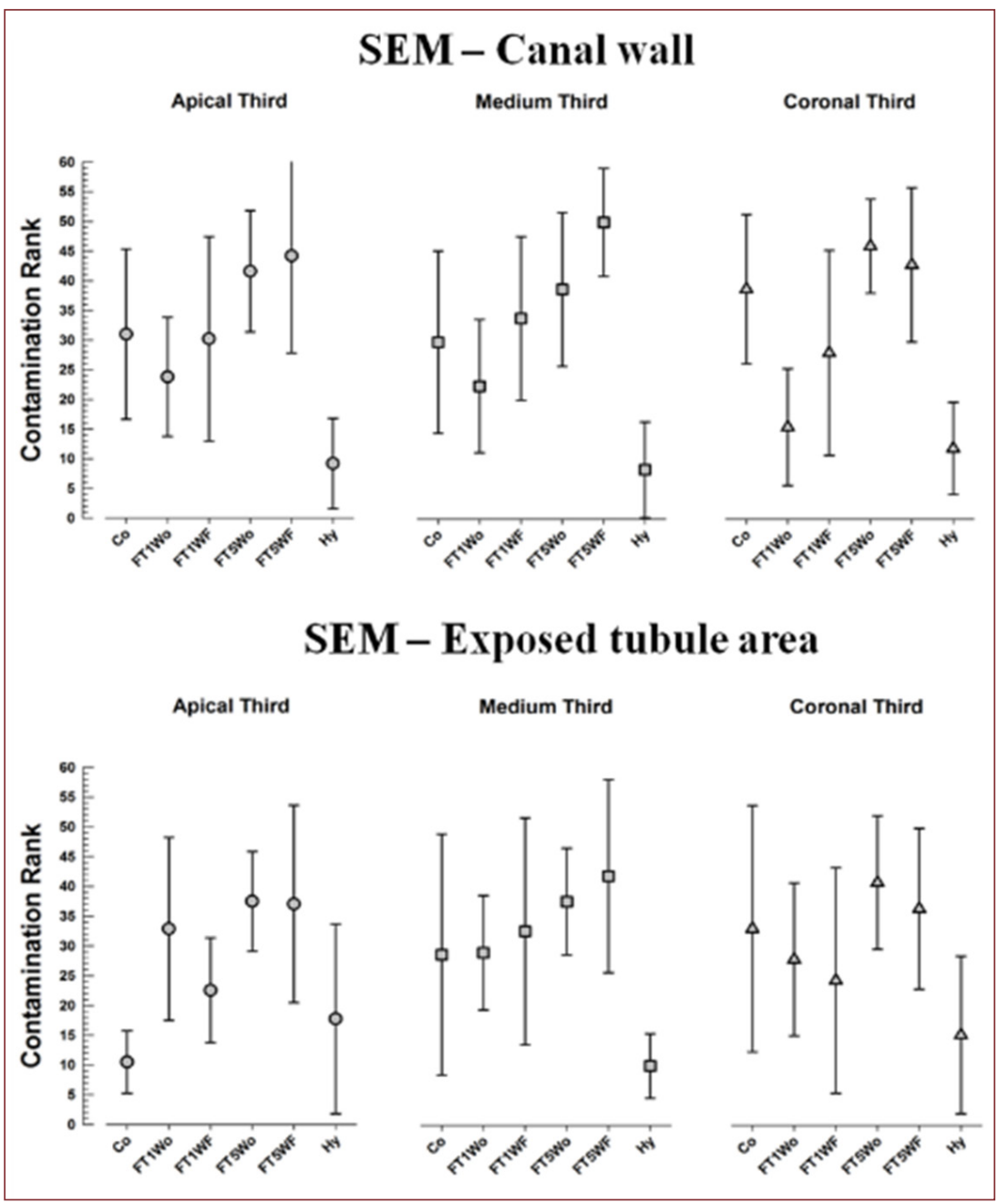

Figure 1. Graph: SEM position ranks: Co (group 1) = control with distilled water; FT1Wo (group 2) = photodynamic therapy and 1 minute pre-irradiation time without optic fiber; FT1WF (group 3) = photodynamic therapy and 1 minute pre-irradiation with optic fiber; FT5Wo (group 4) = photodynamic therapy and 5 minutes pre-irradiation without optic fiber; FT5WF (group 5) = photodynamic therapy and 5 minutes pre-irradiation with optic fiber; Hy (group 6): $2 \%$ sodium hypochlorite; contamination levels at canal wall and exposed tubule area.

Table 1. Comparison of position ranks of contamination levels between different cleaning treatments applied to root canals of bovine incisors.

\begin{tabular}{|c|c|c|c|c|c|c|c|}
\hline Variable & Group 1 & Group 2 & Group 3 & Group 4 & Group 5 & Group 6 & $P$ \\
\hline Canal Wall & $n=10$ & $n=10$ & $n=10$ & $n=10$ & $n=10$ & $n=10$ & \\
\hline Apical third & $31(14.3)^{b . c}$ & $23.8(10)^{a . b}$ & $30.2(17.2)^{\text {b.c* }}$ & $41.6(10.2)^{c}$ & $44.2(16.4)^{\mathrm{c}}$ & $9.2(7.6)^{\mathrm{a}}$ & $<0.001$ \\
\hline Middle third & $29.8(15.3)^{b . c}$ & $22.4(11.2)^{a . b}$ & $33.8(13.7)^{b . c}$ & $38.7(12.9)^{\mathrm{c.d}}$ & $50(9.1)^{d}$ & $8.3(8)^{\mathrm{a}}$ & $<0.001$ \\
\hline Coronal third & $38.7(12.5)^{\mathrm{cd} \star *}$ & $15.5(9.8)^{a . b}$ & $28(17.2)^{b . c}$ & $46(7.9)^{d}$ & $42.8(12.9)^{c . d}$ & $11.9(7.7)^{a}$ & $<0.001$ \\
\hline Exposed tubules & $\mathrm{n}=10$ & $n=10$ & $n=10$ & $\mathrm{n}=10$ & $\mathrm{n}=10$ & $n=10$ & \\
\hline Apical third & $10.5(5.2)^{a \star \star \star}$ & $32.8(15.3)^{\mathrm{bc} *}$ & $22.5(8.8)^{\text {a.b.c.c* }}$ & $37.5(8.3)^{c}$ & $37(16.5)^{c}$ & $17.7(15.9)^{a . b}$ & $<0.001$ \\
\hline Middle third & $28.7(20.2)^{a . b}$ & $29(9.6)^{a . b *}$ & $32.6(19)^{b c}$ & $37.6(8.9)^{c d}$ & $41.9(16.2)^{d}$ & $10.1(5.4)^{\mathrm{a}}$ & $<0.001$ \\
\hline Coronal third & $33(20.6)^{c d \star \star}$ & $27.9(12.8)^{\mathrm{ab}}$ & $24.3(18.9)^{\mathrm{bc}}$ & $40.8(11.2)^{d}$ & $36.4(13.5)^{c d}$ & $15.2(13.2)^{a}$ & 0.011 \\
\hline
\end{tabular}

Data are presented as mean ranks (standard deviation). $\mathrm{P}$ = robust significance (Brown-Forsythe) obtained using one-way ANOVA of ranks

Different letter indicate significant differences, in the same line, according to Tukey post hoc test.

* sample size reduced to $n=9 ; * *$ : sample size reduced to $n=8 ; * * *$ sample size reduced to $n=6$. 
At the exposed tubule area, group 1 had the best results in the apical third, there were statistically significant differences between this group and groups 2, 4 and $5(\mathrm{p}<0,001)$. In this third, group 3 had the best results between groups of photodynamic therapy but there were no statistically significant differences with other groups.

At the exposed tubule area, group 6 had the best results in the middle and coronal third. There were statistically significant differences between group 6 and groups 3,4 and 5 in the middle third $(\mathrm{p}<0,001)$, and between group 6 and groups 1, 3, 4 and 5 in the coronal third $(\mathrm{p}=0,011)$. Between groups of photodynamic, group 2 had the best results in the middle third and group 3 in the coronal third. There were statistically significant differences between group 2 and groups 4 and 5 in the middle third $(\mathrm{p}<0,001)$.

No differences in disinfection of root canals were found when optic fiber was used for photodynamic therapy.
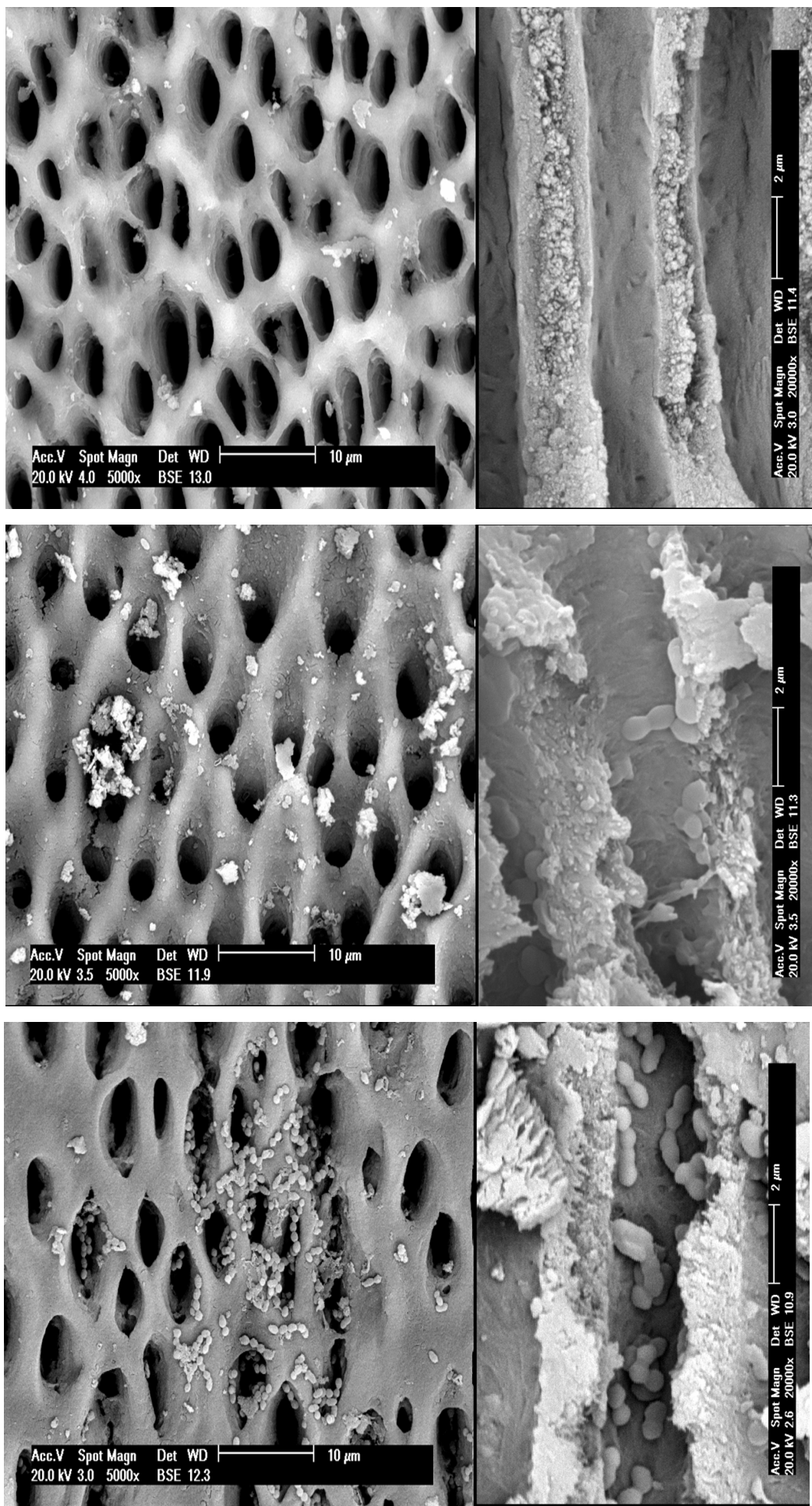

Figure 2. Group 6 (sodium hypochlorite) displaying biofilm of $E$. faecalis in SEM in the middle third (left: canal wall 5000X; right: exposed tubule area 20000X)

Figure 3. Group 2 (photodynamic therapy and 1 minute pre-irradiation time without optic fiber) displaying biofilm of $E$. faecalis in SEM in the middle third (left: canal wall 5000X right: exposed tubule area 20000X)

Figure 4. Group 1 (control group) displaying biofilm of $E$. faecalis in SEM in the middle third (left: canal wall 5000X; right: exposed tubule area 20000X) 


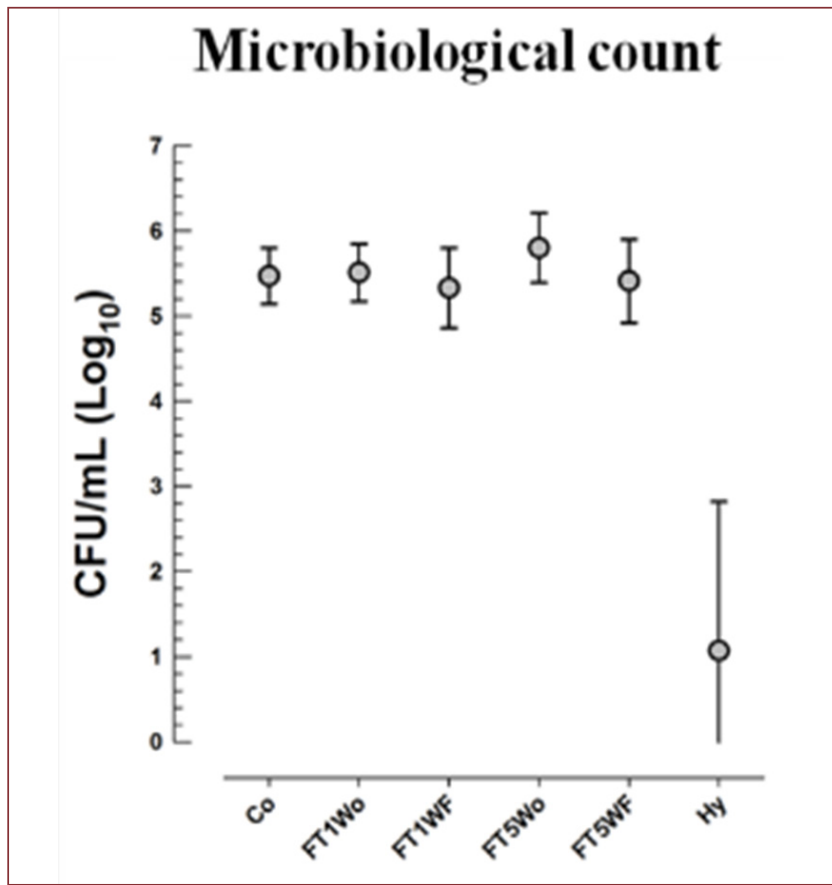

Figure 5. Microbiological tests: Co (group 1) = control with distilled water; FT1Wo (group 2) = photodynamic therapy and 1 minute preirradiation time without optic fiber; FT1WF (group 3) = photodynamic therapy and 1 minute pre-irradiation with optic fiber; FT5Wo (group 4) = photodynamic therapy and 5 minutes pre-irradiation without optic fiber; FT5WF (group 5) = photodynamic therapy and 5 minutes pre-irradiation with optic fiber; Hy (group 6): $2 \%$ sodium hypochlorite; counting of CFU/ml $(\log 10)$.

\section{Microbiological analysis}

Group 1 had a mean count of $5.47 \log \mathrm{CFU} / \mathrm{mL}$; Group 2: $5.51 \log$ CFU/mL; Group 3: $5.33 \log \mathrm{CFU} / \mathrm{mL}$; Group 4: $5.80 \log$ CFU/mL; Group 5: $5.41 \log$ CFU/mL and Group 6: $1.07 \log \mathrm{CFU} / \mathrm{mL}$.

Group 6 had the best results and there were statistically significant differences between this group and groups 1,2 , 3,4 and $5(p=0,000)$. There were no statistically significant differences between groups 1, 2, 3, 4 and 5 .

\section{DISCUSSION}

Photodynamic therapy has gradually expanded from Medicine to Dentistry, and one of its uses is to be an alternative to cleaning and reducing microorganisms within root canals. In this study, photodynamic therapy was applied to an E. faecalis biofilm grown in root canals of bovine teeth.

Bovine teeth were chosen because it has already been demonstrated that there are no differences in physical properties between bovine and human dentin in permanent teeth [13]. Moreover, it was possible to obtain samples of similar age and dentin properties, and it was possible to distribute teeth of a single animal into several experimental groups, which reduced the number of variables in clinical trials.
Biofilm found in vivo in teeth with apical periodontitis is mature, strongly adhered to the substrate and penetrating into dentinal tubules, which make it more resistant to cleaning and shaping [14]. To obtain consistent and organized biofilm samples, E. faecalis was incubated for 60 days. A previous study determined that there is marked invasion of E. faecalis into dentinal tubules at 56 days [15].

The target tissues should be previously exposed to dyes before exposure to light radiation, called preirradiation time (PIT). Blue dyes are potent sensitizers for a certain group of bacteria when irradiated with laser that emits visible red light [16]. Ortho-toluidine blue (tolonium chloride) and methylene blue, associated with laser light with a wavelength of about $630 \mathrm{~nm}$, have the best results in eliminating bacteria and fungi [17]. Methylene blue and ortho-toluidine blue were tested to find out which one would have a greater bactericide action against different types of bacteria, both Gram positive and Gram negative. Both were efficient when red-emitting laser was used, but ortho-toluidine blue had the best bactericide effect [12]. Therefore, ortho-toluidine blue (tolonium chloride) was the choice of photosensitizer for this study.

Some authors adopted a 2 minute PIT [7,18], whereas others used 5 minutes $[9,19]$ and even 10 minute PIT [20]. In the present study, was used 1 minute PIT, as recommended by the PAD Plus manufacturer, and 5 minute PIT, according to literature, with or without optic fiber.

The amount and distribution of bacteria on the surface of biofilm may be compared between treatments when the samples are analyzed using SEM [14,21]. However, SEM cannot demonstrate bacteria viability. To address this problem, the microbiological examination was performed, enabling the counting of the CFU's.

Microbiological results revealed that there were no differences when different photosensitizers PIT's were used: 1 minute with photosensitizer stirring and 5 minutes. No differences were found in canal disinfection when the optic fiber was coupled to the LED tip. The stationary technique was chosen because the comparison of three different techniques, the stationary and the helicoidal techniques and application without optic fiber, did not reveal any differences between them [7].

Both microbiological tests and SEM analysis of the canal wall demonstrated the superiority of sodium hypochlorite to disinfect the root canal.

Between groups of photodynamic therapy, SEM results of the canal wall revealed superiority of group 2 . Microbiological and SEM results showed that photodynamic therapy does not disinfect root canals when applied alone to canals contaminated with $E$. faecalis. No differences in disinfection of root canals were found when an optic fiber was used for photodynamic therapy. However when different photosensitizer PIT were tested, there were statistically significant differences between groups of 1 minute PIT and groups of 5 minute PIT, and the groups that utilized 1 minute had the best results. 
SEM analysis of the exposed tubule area was inconclusive, demonstrating that none of the proposed treatments was effective in eliminating bacteria from inside the dentinal tubules.

Study demonstrated a bactericide effect when the photodynamic therapy was associated with cleaning and shaping of root canals using sodium hypochlorite as an irrigating solution [22], together with inactivation of endodontic pathogens without affecting host cell viability [23]. Therefore, our findings demonstrated that photodynamic therapy alone does not affect a well-structured biofilm, such as the one produced by $E$. faecalis.

These results are consistent with the findings of Seal et al. [10] and Meire et al. [24], who found that the combined use of photosensitizer and laser had a bactericide effect, but was not capable of completely removing biofilm from root canals. Those studies were similar to these that applied PDT with ortho-toluidine blue as a photosensitizer, but differed in whether they used or not an optic fiber. No differences in disinfection of root canals were found when optic fiber was used for photodynamic therapy.

More important than our results, which are contributions to the establishment of a photodynamic therapy protocol, this study confirmed the effectiveness of a protocol of contamination, culture and material collection for later bacterial count [25]. In this study, samples were extracted bovine teeth, but this protocol can also be used with extracted human teeth.

\section{CONCLUSION}

Considering such results, we believe that photodynamic therapy should not be used alone in the disinfection of root canals, but it may be a complementary method for disinfection performed using different cleaning protocols. More studies are needed to assess the removal of bacteria from dentinal tubules.

\section{ACKNOWLEDGEMENT}

The authors deny any conflicts of interest related to this study.

\section{REFERENCES}

1. Sundqvist G, Figdor D, Persson S, Sjögren U. Microbiologic analysis of teeth with endodontic treatment and the outcome of conservative retreatment. Oral Surg Oral Med Oral Pathol Oral Radiol Endod 1998;85:86-93. https://doi.org/10.1016/S1079-2104(98)90404-8

2. Molander A, Reit C, Dahlén G, Kvist T. Microbiological Status of root-filled teeth with apical periodontis. Int Endod J 1998;31(1):1-7. https://doi. org/10.1046/j.1365-2591.1998.t01-1-00111.x

3. Love RM. Enterococcus faecalis - a mechanism for its role in endodontic failure. Int Endod J 2001;34(5):399-405. https://doi.org/10.1046/j.1365 2591.2001.00437.x

4. Orstavik D, Haapasalo M. Disinfection by endodontic irrigants and dressings of experimentally infected dentinal tubules. Endod Dent Traumatol 1990;6(4):142-9. https://doi.org/10.1111/j.16009657.1990. tb00409.x

5. Byström A, Sundqvist $G$. The antibacterial action of sodium hypochlorite and EDTA in 60 cases of endodontic therapy. Int Endod J 1985;18(1): 35-40. https://doi.org/10.1111/j.1365-2591.1985.tb00416.x
6. Peters LB, Wesselink PR, Moorer WR. The fate and the role of bacteria left in root dentinal tubules. Int Endod J 1995;28(2):95-9. https://doi. org/10.1111/j.1365-2591.1995.tb00166.x

7. Cavalheiro FM. Assessment of bacterial reduction in contaminated root canals comparing three irradiation techniques with low power laser associated with a photosensitizer, an in vitro study [Dissertation]. São Paulo: Dental School of USP; 2007.

8. Williams JA, Pearson GJ, Colles MJ. Antibacterial action of photoactived disinfection $\{P A D\}$ used on endodontic bacteria in planktonic suspension and in artificial and human root canals. J Dent 2006;34(6):363-71. https:// doi.org/10.1016/j.jdent.2005.08.002

9. Kairalla EC. Study of the intracanal microbial reduction using a lowpower laser combined with a photosensitizer and a high-power laser [Dissertation]. São Paulo: Dental School of USP;2006

10. Seal GJ, NG YL, Spratt D, Bhatti M, Gulabivala K. An in vitro comparison of the bactericidal efficacy of lethal photosensitization or sodium hyphochlorite irrigation on Streptococcus Intermedius biofilm in roo canals. Int Endod J 2002;35(3):268-74. https://doi.org/10.1046/j.13652591.2002.00477.x

11. Lee MT, Bird PS, Walsh LJ. Photo-activated disinfection of the root canal: a new role for lasers in Endodontics. Aust Endod J 2004;30(3): 93-98. https://doi.org/10.1111/j.1747-4477.2004.tb00417.x

12. Usacheva MN, Teichert MC, Biel MA. Comparison of the methylene blue and toluidine blue photobactericidal efficacy against gram-positive and gram-negative microorganisms. Lasers Med Surg 2001;29:165-73. https:// doi.org/10.1002/lsm.1105

13. Schilke R, Bauss O, Lisson JA, Schuckar M, Geurtsen W. Bovine dentin as a substitute for human dentin in shear bond strength measurements. Am J Dent 1999:12(2):92-96.

14. Bhuva B, Patel S, Wilson R, Niazi S, Beighton D, Manocci F. The effectiveness of passive ultrasonic irrigation on intraradicular Enterococcus faecalis biofilms in extracted single-rooted human teeth. Int Endod J 2010;43:241-250. https://doi.org/10.1111/j.1365-2591.2009.01672.x

15. Chivatxaranukul P, Dashper SG, Messer HH. Dentinal Tubule invasion and adherence by Enterococcus Faecalis. Int Endod J 2008;41:873-882. https://doi.org/10.1111/j.1365-2591.2008.01445.x

16. Walsh, LJ. The current status of low level laser therapy in dentistry. Part 2. Hard tissue applications. Aust Dent J 1997:42(5):302-6. https://doi. org/10.1111/j.1834-7819.1997.tb00134.x

17. Gonçalves, L. Effect of the photosensitizers used during the intracana laser irradiation. [Dissertation]. São Paulo: Dental School of USP;2005.

18. Souza LC, Brito PRR, Oliveira JCM, Alves FRF, Moreira EJL, SampaioFilho HR, et al. Phodynamic Therapy with Two Differents Photosensitizers as a Supplement to Instrumentation/Irrigation Procedures in Promoting Intracanal Reduction of Enterococcus faecalis. J Endod 2010;36: 292-6. https://doi.org/10.1016/j.joen.2009.09.041

19. Fonseca MB, Júnior PO, Pallota RC, Filho HF, Denardin OV, Rapoport A et al. Photodynamic Therapy for Root Canals Infected with Enterococcus faecalis. Photomed Laser Surg 2008;26(3):209-13. https://doi.org/10.1089/ pho.2007.2124

20. Fimple JL, Fontana CR, Foschi F, Ruggiero K, Song X, Pagonis TC, et al Photodynamic Treatment of Endodontic Polymicrobial Infection In Vitro. J Endod 2008;34:728-34. https://doi.org/10.1016/j.joen.2008.03.011

21. Estrela C, Sydney GB, Figueiredo JAP, Estrela CRA. A Model System to Study Antimicrobial Strategies on Endodontic Biofilms. J Appl Ora Sci 2009;17:87-91. https://doi.org/10.1590/S1678-77572009000200003

22. Ng R, Singh F, Papamanou DA, Song X, Patel C, Holewa C, et al Endodontic Photodynamic Therapy Ex Vivo. J Endod 2011:37:217-22. https://doi.org/10.1016/j.joen.2010.10.008

23. Xu Y, Young MJ, Battaglino RA, Morse LR, Fontana CR, Pagonis TC, et al. Endodontic Antimicrobial Photodynamic Therapy: Safety Assessment in Mammalian Cell Cultures. J Endod 2009;35:1567-72. https://doi. org/10.1016/i.joen.2009.08.002

24. Meire MA, Prijck KD, Coenye T, Nelis HJ, Moor RJGD. Effectiveness of different laser systems to kill Enterococcus faecalis in aqueous suspension and in an infected tooth model. Int Endod J 2009;42:351-9. https://doi. org/10.1111/j.1365-2591.2008.01532.x

25. Gründling GL, Zechin JG, Jardim WM, Oliveira SD, Figueiredo JAP. Effect of Ultrasonics on Enterococcus faecalis Biofilm in a Bovine Tooth Model. J Endod 2011;37(8):1128-33. https://doi.org/10.1016/j.joen.2011.05.006 